\title{
Çelik Endüstrisi için Alüminyum Cüruflarından Flaks Üretimi
}

\author{
${ }^{* 1}$ Nedim Sözbir, ${ }^{2}$ Aynur Manzak, ${ }^{3}$ Mustafa Akçil, ${ }^{4}$ Asude Ateş \\ ${ }^{1}$ Sakarya Üniversitesi, Mühendislik Fakültesi, Makina Müh. Bölümü, Sakarya \\ sozbir@sakarya.edu.tr \\ ${ }^{2}$ Sakarya Üniversitesi, Fen Edebiyat Fakültesi, Kimya Bölümü, Sakarya \\ manzak@sakarya.edu.tr \\ ${ }^{3}$ Sakarya Üniversitesi, Mühendislik Fakültesi, Malzeme ve Met. Müh. Bölümü, Sakarya \\ makcil@sakarya.edu.tr \\ ${ }^{4}$ Sakarya Üniversitesi, Mühendislik Fakültesi, Çevre Müh. Bölümü, Sakarya \\ aates@sakarya.edu.tr \\ Geliş Tarihi: 2017-02-05 Kabul Tarihi: 2018-01-20
}

\section{$\ddot{\mathbf{O z}}$}

Alüminyum cürufları birincil ve ikincil alüminyum üretim sonucu oluşan atıklardır. Bu atıklar beyaz ve siyah cüruf olarak adlandırılır. Bu atık cüruflar içerisindeki metalik alüminyum miktarına göre sınıflandırılırlar. Beyaz cüruf kara cürufa göre daha fazla alüminyum metali ihtiva etmektedir. Beyaz cürufun içerdiği metalik alüminyum miktarı \% 15-70 arasında değişmektedir. Kara cüruf ise \%12 ila 18 arasında alüminyum metali ve daha çok alüminyum oksit ihtiva etmektedir. Kara cüruf ikincil üretim sonucu atık olarak çıtığı için cürufun içerisinde yüksek miktarda (\% 40' dan daha fazla) tuz bileșenleri bulunmaktadır. Tehlikeli atık olarak kabul edilen alüminyum cürufları içerisindeki tuzlar (azot, flor, klor vs) yıkanmak suretiyle alınmaktadır. Bu tuzların limit değerleri ve cüruf içindeki silisyum dioksit, karbon ve nem içeriği TS 13644 uygun olması gerekmektedir. TS 13644 uygun olarak olarak alüminyum cürufundan flaks ürün yapılması mümkün olmaktadır. İçerisindeki tuzlardan arındırılan cüruf, alüminyum metali ve alüminyum oksit miktarlarına göre gruplandırılmaktadır. 10$100 \mathrm{~mm}$ boyutlarında pelet veya $2-100 \mathrm{~mm}$ arasında peletlenmemiş parçacık boyutlarında flaks olarak üretilmektedir. Bu flaks, çelik endüstrisi için deoksidasyon ve cüruf çöktürücü ürün olarak kullanılabilecektir. Alüminyum üretimi yapan tesislerin atığı olan alüminyum cürufun tekrar geri kazanım ile çelik sanayinde oksit giderici ve cüruf çöktürücü flaks üretimi yapılarak ülke ekonomisine kazandırılacaktır. Ayrıca cüruftaki tuzların çevreye zarar vermeleri önlenmiş olacaktır.

Anahtar kelimler: Alüminyum cüruf, deoksidasyon ve cüruf çöktürücü, flaks

\section{Flake Production from Aluminum Slags for Steel Industry}

\author{
*11Nedim Sözbir, ${ }^{2}$ Aynur Manzak, ${ }^{3}$ Mustafa Akçil, ${ }^{4}$ Asude Ateş \\ ${ }^{1}$ Sakarya University, Faculty of Engineering, Mechanical Eng. Department, Sakarya \\ sozbir@sakarya.edu.tr \\ ${ }^{2}$ Sakarya University, Faculty of Arts and Sciences, Department of Chemistry, Sakarya \\ manzak@sakarya.edu.tr \\ ${ }^{3}$ Sakarya University, Faculty of Engineering, Materials and Met. Eng. Department, Sakarya \\ makcil@sakarya.edu.tr \\ ${ }^{4}$ Sakarya University, Faculty of Engineering, Environmental Eng. Department, Sakarya \\ aates@sakarya.edu.tr
}

\begin{abstract}
Aluminum slags are wastes formed as a result of primary and secondary aluminum production. These wastes are called white and black slag. These waste slags are classified according to the amount of metallic aluminum in the slags. White slag contains more aluminum metal than black slag. The amount of metallic aluminum contained in the white slag ranges between 15-70\%. Black slag contains between 12 and $18 \%$ of aluminum metal and contains mostly aluminum oxide. Because of black slag being ensued by secondary production, it contains high amount of salt constituents (more than 40\%). Salts considered hazardous (nitrogen, fluorine, chlorine, etc.) in aluminum slags
\end{abstract}


are taken via washing. The limit values of these salts and the content of silicon dioxide, carbon and moisture in the slag should be in accordance with TS 13644. According to TS 13644, it is possible to make flux products from aluminum slag. The slag, which is purified from its salt content, is grouped according to the amount of aluminum metal and aluminum oxide. It is produced as a pellet with dimensions of $10-100 \mathrm{~mm}$ or as a flux of non-pelletized particle size of $2-100 \mathrm{~mm}$. This flux can be used as a deoxidation and slag precipitation product for the steel industry. By recycling aluminum slag, which is the waste of the aluminum production facilities, antioxidant and slag precipitator flux can be produced in steel industry and can contribute to the national economy. Likewise, the salt in the slag will be prevented from harming the environment.

Keywords: Aluminum slag, deoxidation and slag precipitator, flux

\section{GíRiş}

Alüminyum en çok bulunan bir metal olup ve oksijen ve silokon dan sonra dünya kabuğunda en fazla bulunan üçüncü elementtir. Doğal olarak serbest bir element olarak yeryüzü kabuğunda bulunmaz. Her alanda tercih edilen ve geniş kullanım alanına sahip olan alüminyum yeryüzü kabuğunda bulunan boksit madeninden elde edilmektedir. Farklı sektörlerde kullanılan alüminyum, geri kazanım yöntemleri ile ülke ekonomisine katkı sağlaması açısından birçok araştırma, makale ve teknik çalışmanın konusu olmuştur. Alüminyum, ulaştırma, havacılık, uzay, denizcilik, paketleme ve konstrüksiyon sektörü gibi pek çok yerde kullanılmaktadır. Bu endüstriler için oldukça kritik bir malzemedir. Bugün alüminyum, iki farklı metod ile üretilmektedir. Bunlardan ilki birincil alüminyum üretim yöntemi olan cevherden (boksit) ve ikincil üretim yöntemi olan hurda veya cüruftan geri dönüşüm yöntemidir. Alüminyum cürufu ise birincil ve ikincil alüminyum üretimi sonucu ortaya çıkan tehlikeli atıklardır. Bu cüruflar alüminyum içeriğine göre beyaz ve kara cüruf olarak sinıflandırılır. Beyaz cüruf, yüksek alüminyum metali içermekte olup, birincil ve ikincil üretim sonucu alüminyumun ergitilmesi sonucu ortaya çıkan atıktır. Kara cüruf ise düşük alüminyum metali içermekte olup, geri dönüşüm sonucu ortaya çıkan atıktır. Beyaz cüruf $\% 15$ ila 70 (ortalama \%50) arasında geri dönüşebilir metalik alüminyum içerir. Bugün en iyi teknolojilerle alüminyum cürufündan \% 94'e kadar geri dönüşüm yapmak suretiyle alüminyum üretilmesi mümkündür. Kara cüruf ise alüminyum oksitli çüruf parçacıklarından oluşmaktadır. Geri dönüşebilen alüminyum değeri \% 12 ila 18 arasında olup yüksek miktarda tuz (tipik olarak \% 40'dan fazla) içerir. Ayrıca ikincil alüminyum üretimi sonucunda atık olarak alüminyum tuz cürufu (alüminyum tuz kek olarak da bilinir) ortaya çıkmaktadır. Tuz kekinde \% 15-30 alüminyum oksit, \% 30-55 sodyum klorür,\% 15-30 potasyum klorür, \% 5-7 metalik alüminyum ve yabancı maddeler (karbürler, nitrürler, sülfitler ve fosfitler) içerir. İkincil alüminyum üretiminde, ton başına oluşan atık olan tuz keki miktarı 200 ila 500 kg değişir. Tuz keki, toksik ve tehlikeli atık olarak siniflandirılır [1-3].
2002 yılında İngiltere'de yapılan bir araştırmada 200 bin ton beyaz ve kara alüminyum cürufu, alüminyum endüstriden atık olarak oluştuğu belirtilmiştir. Dünya da 2009 y1lında birincil alüminyum üretimi 36 milyon civarındadır. Bu miktar her yıl yaklaşık olarak \% 5-6 artmaktadır. 2010 yılında dünya da 56 milyon ton alüminyum üretilmiş, bunun 18 milyon tonu ise hurda alüminyum kullanılarak üretilmiştir. 2020 yılında dünyadaki alüminyum ihtiyacı 97 milyon ton olacağı öngörülmekedir. Bunun 37 milyon tonu ise hurdadan üretilecektir. Bugün ise Avrupa da alüminyum üretiminin \% 50 'sinden fazlası hurda alüminyumun geri dönüşümünden elde edilmektedir. $\mathrm{Bu}$ oran gittikçe artacağ 1 görülmektedir. A.B.D.'de yeni alüminyum malzemelerin \%55'i kullanılmış alüminyumdan üretilmektedir. 2000 yılında 100.8 milyar alüminyum kutunun 62.6 milyar adeti geri kazanılmış alüminyumdan üretilmiştir. Yaklaşık olarak, dünyada her yıl 4 milyon ton kadar beyaz cüruf ve 1 milyon tondan daha fazla kara cürufun atık olarak oluştuğu rapor edilmiştir. Bu atıkların yaklaşık \% 95'i de gömülmek suretiyle bertaraf edilmektedir. Atıklar içeriisnde bulunan tuzlar ciddi çevre problemi oluşturmaktadır [1-3].

Boksitten bir ton alüminyum üretimi için yaklaşık 17000 kWh enerji gerekirken, geri dönüşümle aynı miktar alüminyum için $750 \mathrm{kWh}$ enerji harcanmaktadır. İkincil alüminyum üretimini birincil üretim ile mukayese edersek boksitten üretilen enerji harcamasının yaklaşık \% 5' i kadar enerji harcanmakta ve sadece sera gazının \% 5'i kadarı çevreye atılmaktadır. Atığın gömülmek suretiyle bertarafa edilmesi, yerine bu atıkların atığın geri dönüştürülmesi sağlanmalıdır[3,5-6].

Şekil 1'de birincil ve ikincil alüminyum üretiminden atık olarak ortaya çıkan beyaz ve kara alüminyum cürüfları görülmektedir [1]. $\mathrm{Bu}$ çalışmada, ülkemizde birincil ve ikincil alüminyum üretiminden atık olarak ortaya çıkan beyaz ve kara alüminyum cürüfundan, alüminyum metalinin (külçe, vs) geri kazanılması ile elde edilmesi ve özellikle bu cüruflardan ve tuz kekinden çelik endüstrisi için cüruf çöktürücü ve deoksidasyon olarak kullanılacak 
flaks elde edilmesi incelenecektir. Alüminyum cürufları ve ocak kekinden Aralık 2014 yılında çıkarılan TS 13644 “Alüminyum Esaslı FlakslarÇelik Endüstrisi İçin” Standard ile alüminyum cürufları toprağa gömülmeyecek ve çelik üretim sanayisinde, yurt dışından temin edilen oksit giderici flaks (kalsiyum alüminat ve kalsiyum florür) ve

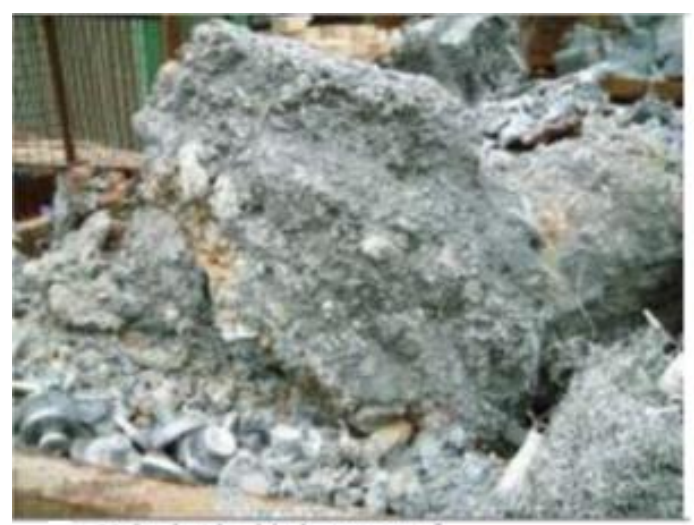

Yoksek Al sahip beyaz ctiruf

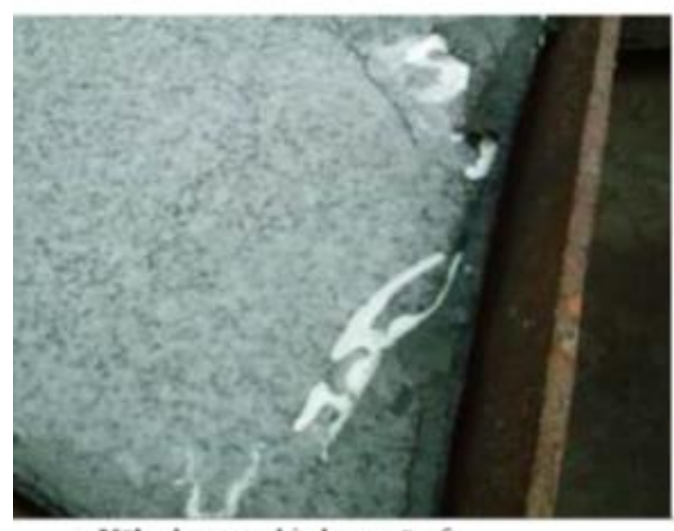

Yoksek muza sahip kara cetruf

Şekil 1. Beyaz ve Kara Alüminyum Cürufu [1]

\section{GERİ DÖNÜŞÜM METODU}

\subsection{Alüminyum Metali Üretimi}

Birincil ve ikincil alüminyum üretimi sonucunda atık olarak çıkan beyaz ve kara cürufları, geri kazanım prosesi uygulanarak alüminyum metali ve alüminyum oksit elde edilmektedir. Özellikle alüminyum metalinin geri kazanılması beyaz cüruf (birincil üretim) geri dönüşüm prosesi uygulanarak alüminyum metalinin \% 99.9 oranında geri kazanılması mümkün olmaktadır. Alüminyum metali geri dönüşüm prosesinin akış şeması Şekil 2'de görülmektedir. Daha çok tercih edilen birincil alüminyum cürufları (ihtiyaç halinde ikincil üretim cürufları kullanılmakta), döner tamburda uygulanan fiziksel işlemle içerisindeki çelik bilyalar sayesinde alüminyum metali üzerindeki alüminyum oksit metalden ayrılır. Alüminyum oksit $2 \mathrm{~mm}$ altı toz cüruf çöktürücü külçe metalik alüminyum yerine oksit giderici ve cüruf çöktürücü "flaks" ürün olarak kullanılması sağlanacaktır. Cüruf ve tuz kekinden flaks üretimi, çevre kirliliğinin önlenmesi ve ülkemizin ekonomik kazanımı için oldukça önemlidir.

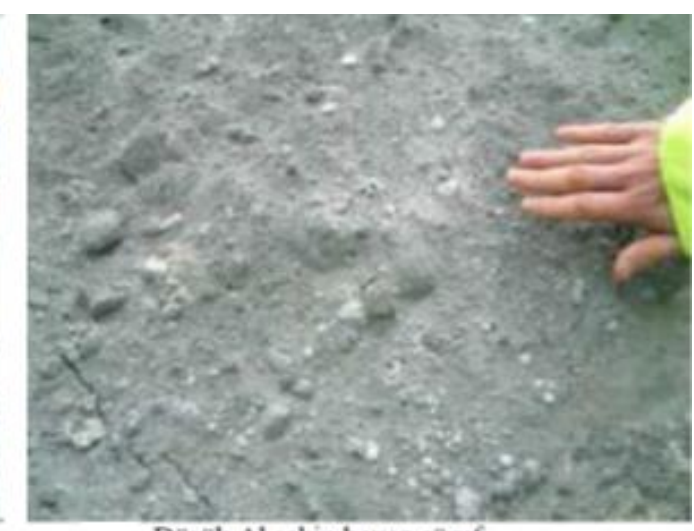

Düşuk Al sahip beyaz cüruf

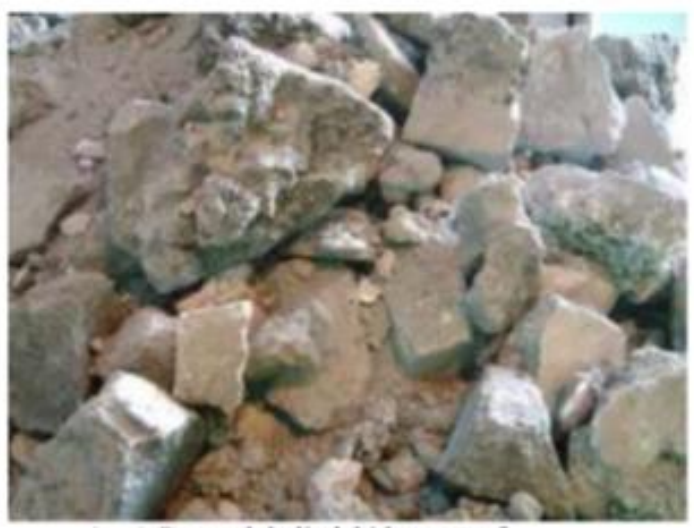

Parçaçık halindeki kara cliruf

boyutundadır. Alüminyum metali tambur dibinde birikirken, bundan çok daha hafif bir malzeme olan alüminyum oksit bir fan yardımı ile çekilmekte ve torba filtrelere verilmektedir. Torba filtrelerde tutulan alüminyum oksit, bunkerde toplanmakta ve bunker tabanından torbalara konularak geçici depolama sahasına alınmaktadır. Tambur tabanında biriken alüminyum metalleri ise, tambur taban kapağı açılarak dışarı alınmakta ve doğrudan ergitme potasına gönerilerek ergitilmesi sağlanır. Ergitme işlemi yaklaşık $750 \quad{ }^{\circ} \mathrm{C} \quad$ sicaklıkta gerçekleştirilmektedir. Potada uygulanan ergitme işlemine bağlı olarak meydana gelen cüruf (tuz keki), işletmede tekrar hammadde olarak alüminyum curüf ile birlikte tekrar kullanılmakta, sıv1 hale gelmiş alüminyum metali ise kalıplara dökülerek külçe alüminyum elde edilmekte ve ambalajlanarak piyasaya arz edilmektedir [5,7-8]. 


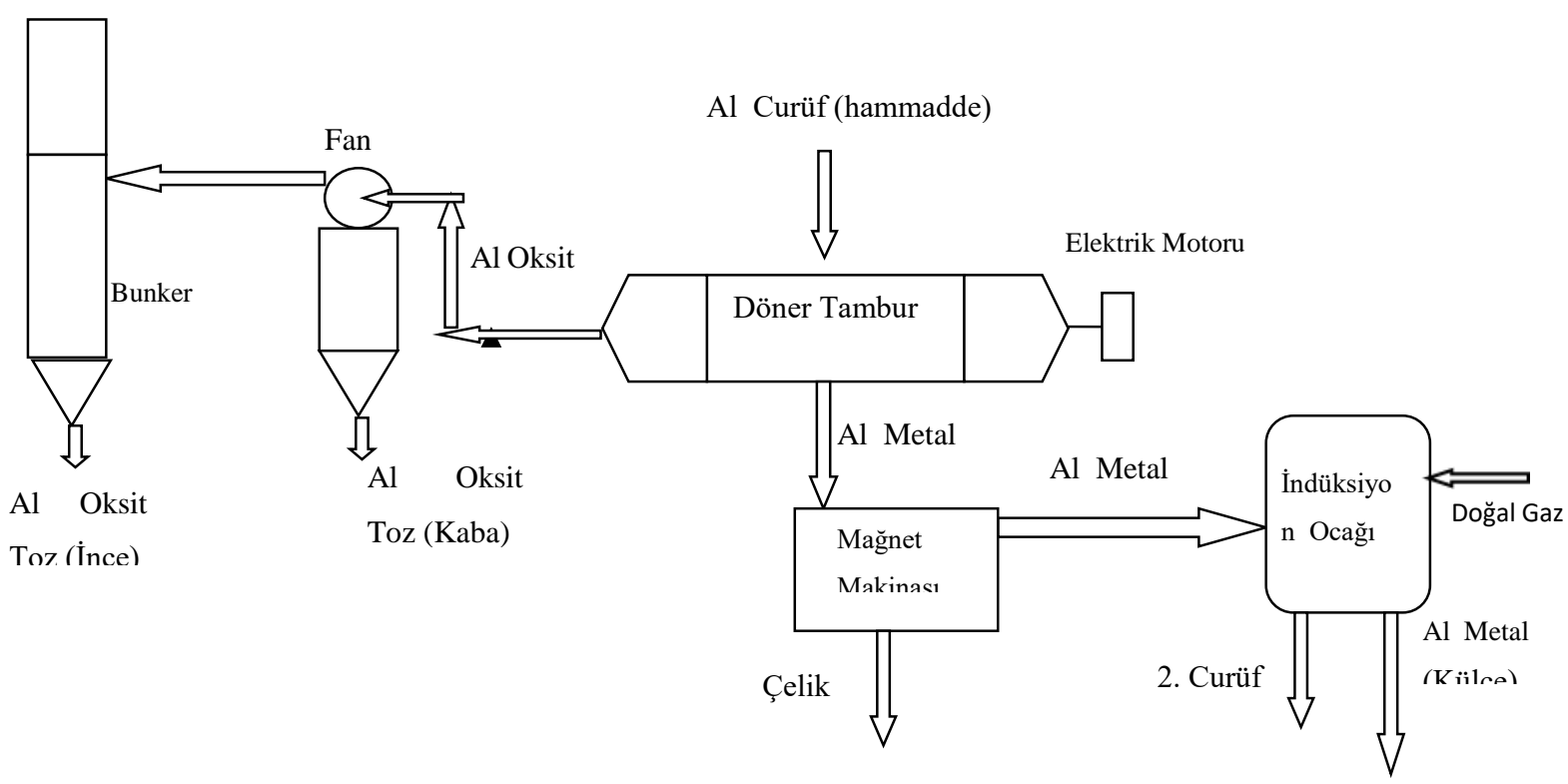

Şekil 2. Örnek Tesiste Alüminyum Geri Kazanım Prosesi.

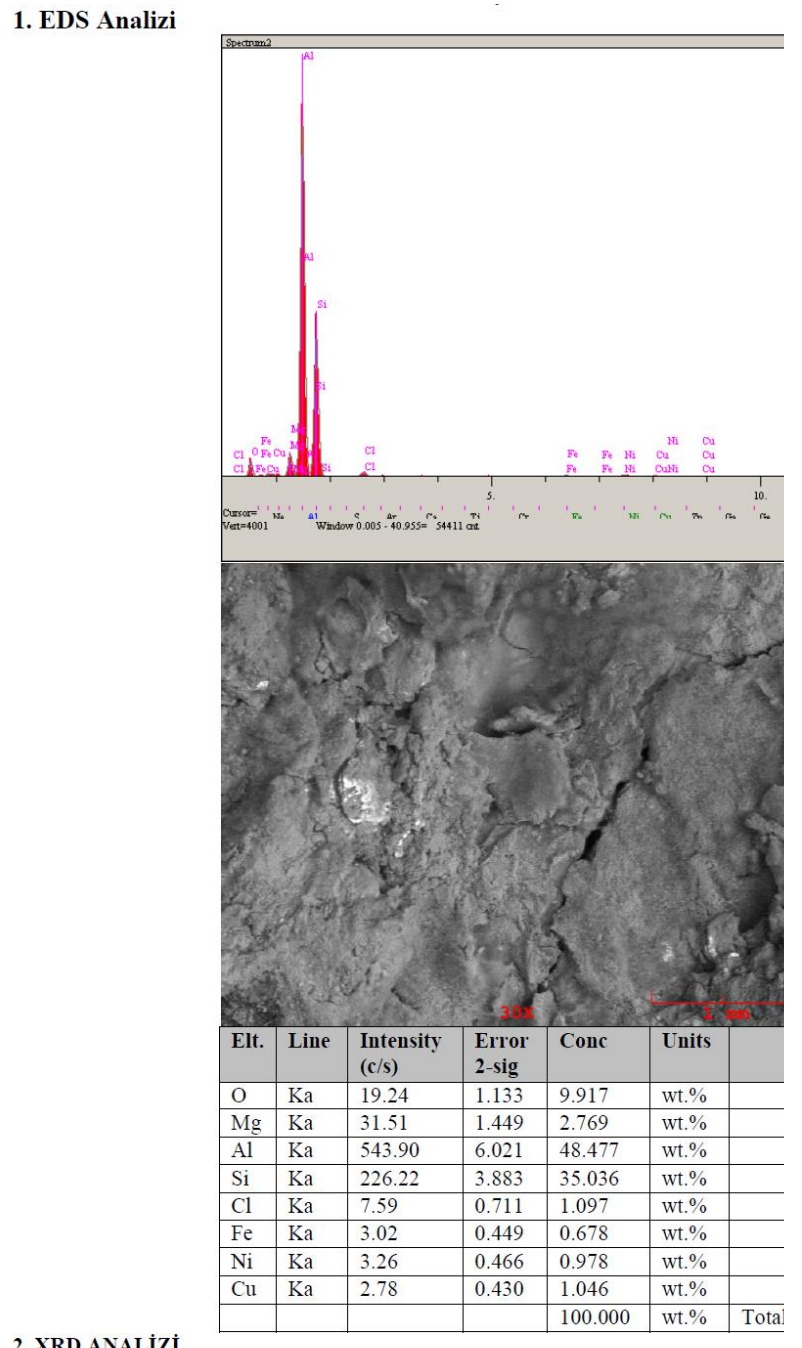

$\mathrm{Al}_{2} \mathrm{O}_{3}: \% 21,07$

Al: $\% 37.32$

Şekil 3. Beyaz Alüminyum Curuf
1.EDS Analizi

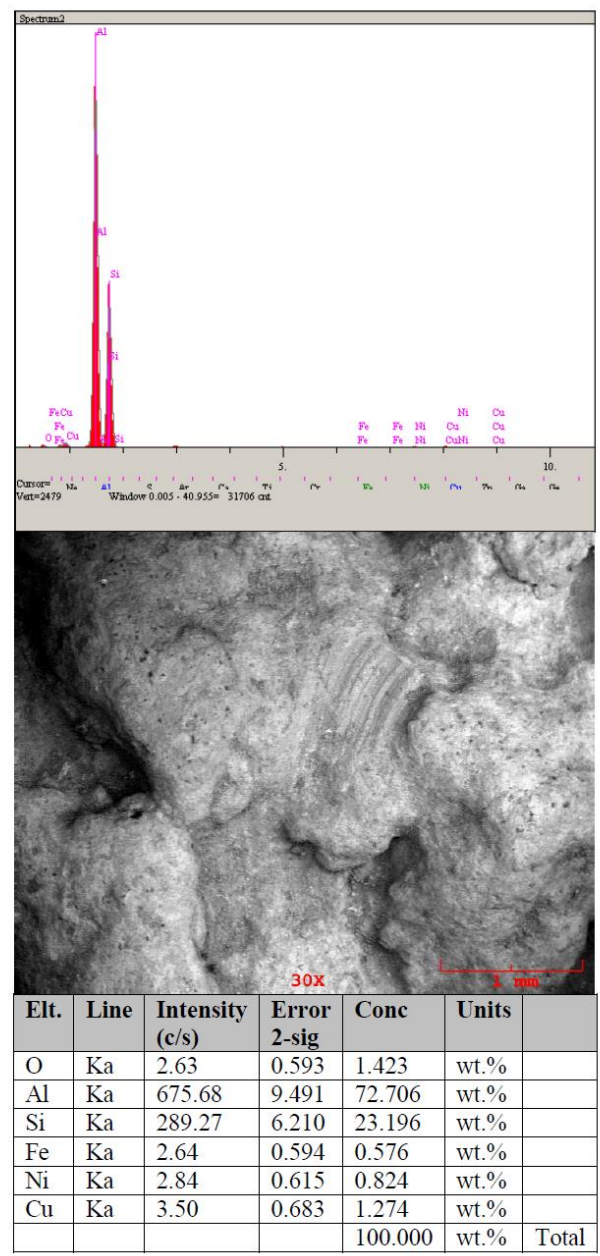

2. XRD ANALİZi $\mathrm{Al}_{2} \mathrm{O}_{3}: \% 3$

$\mathrm{Al}: \quad \% 71.106$

Şekil 4. Tamburdan Çıkan Alüminyum Cüruf 
1.EDS Analizi
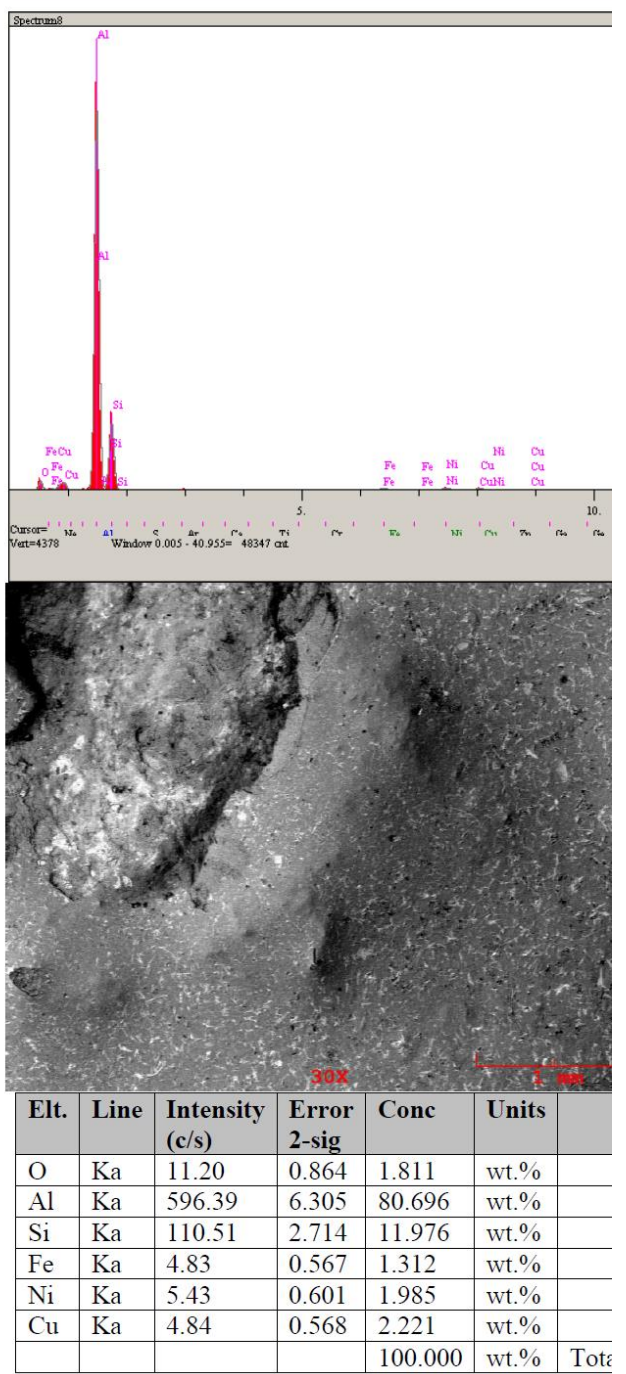

Şekil 5. \% 80 Saflıkta Külçe Alüminyum

\subsection{Flaks Üretimi}

Birincil veya ikincil alüminyum cüruflarından alüminyum metali üretilirken bu proses sonucunda filitrelerde tutulan toz alüminyum oksit ve ocaktan çıkan tuz keki gibi tehlikeli atıklar çelik endüstrisi için oksijen giderici ve curuf akışkanlaştırıcı olarak
1.EDS Analizi

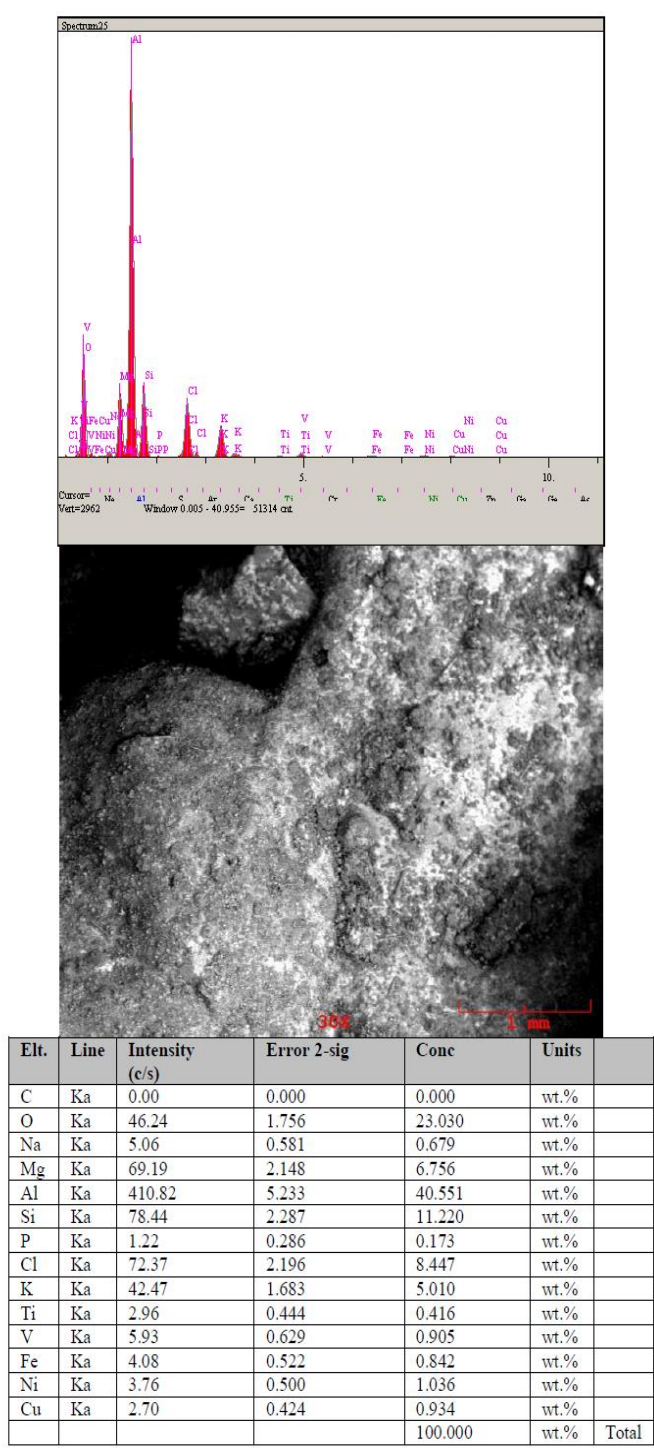

Şekil 6. Potadan Çıkan Cüruf ( Tuz Keki)

flaks üretimi yapılabilmektedir. Bu atıklar TS 13644 standardına uygun olarak yıkanarak, içerisindeki tuzlardan arındırlmak suretiyle flaks üretimi elde edilmektedir. Şekil 7'da örnek tesiste peletlenmemiş flaks (parçacık boyutunda) ve Şekil 8'de peletlenmiş (pelet) flaks üretimi görülmektedir[5,7]. 


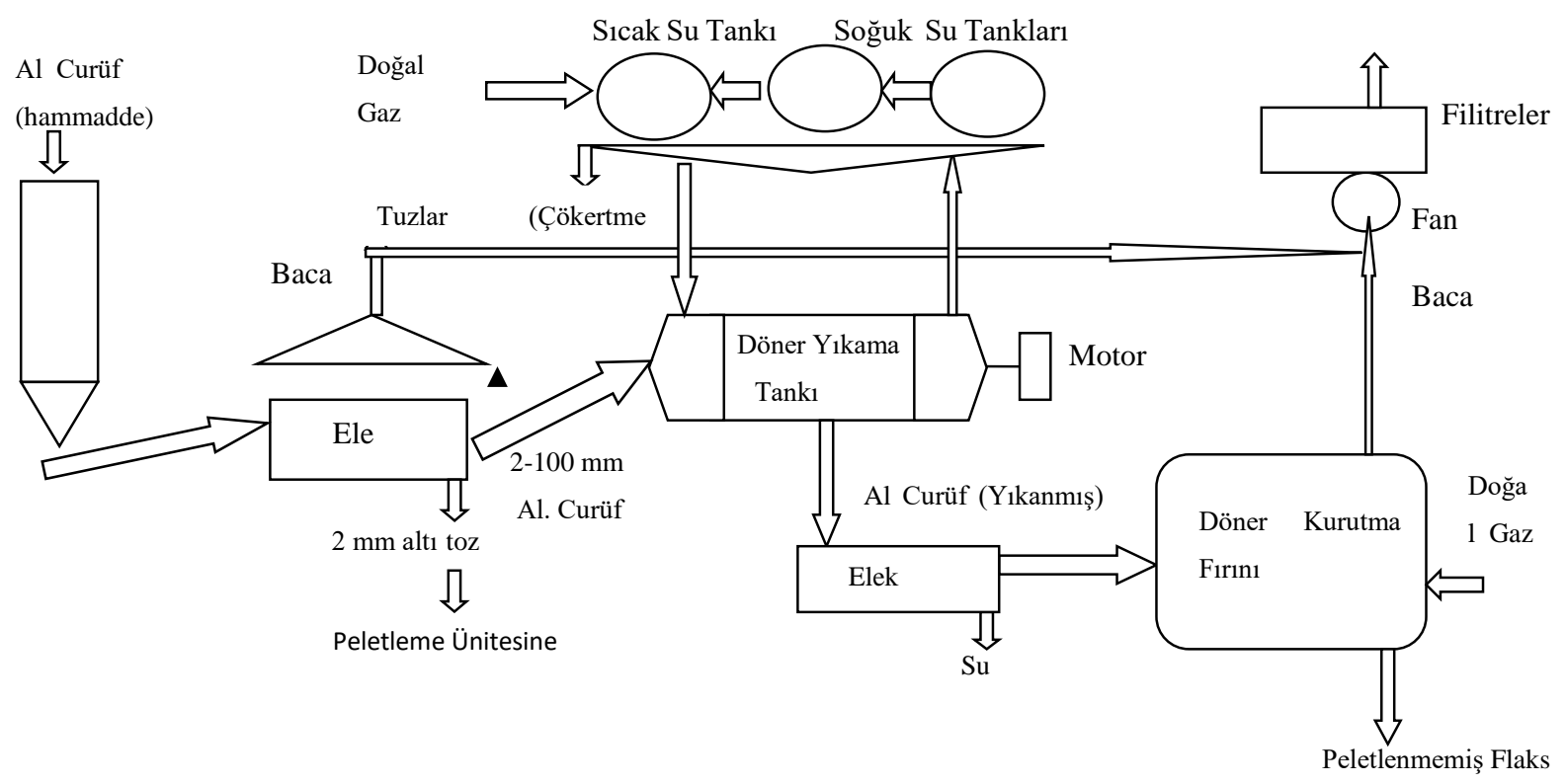

Şekil 7. Örnek Tesiste Peletlenmemiş Flaks Üretimi

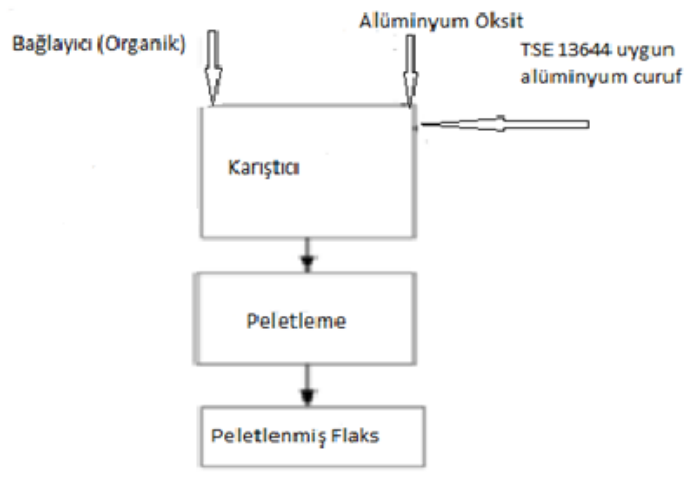

Şekil 8. Peletlenmiş Flaks Üretimi akış şeması

\subsubsection{Alüminyum Cürufunun Yıkanmas}

$\mathrm{Al}_{2} \mathrm{~S}_{3}+3 \mathrm{H}_{2} \mathrm{O} \rightarrow \mathrm{Al}_{2} \mathrm{O}_{3}+3 \mathrm{H}_{2} \mathrm{~S} \uparrow$

$\mathrm{PH}_{3}$ ve $\mathrm{H}_{2} \mathrm{~S}$ meydana gelebilecektir.

Dolayısıyla tuzlu kara cüruflarının yıkanması prosesinde ortaya çıkacak olan gazların hacimsel oranı yaklaşık \% $95 \mathrm{CH}_{4}, \mathrm{H}_{2}$ ve $\mathrm{NH}_{3}$ karışımı ve \% 5 de $\mathrm{PH}_{3}$ ve $\mathrm{H}_{2} \mathrm{~S}$ karışımı olacaktır [6-7].

\subsubsection{Yıkama Sonucunda Çıkan Gazların Deneysel Metod ile İncelenmesi}

Deney düzeneği şekil 9'da görülmektedir. Bu düzenekten iki adet bulunmaktadır. Düzeneklerden birinde, mevcut bütün hammaddeyi temsil edecek şekilde temin edilmiş olan homojen, yıkanmamış alüminyum cürufundan $50 \mathrm{gr}$ alınmış ve oda sıcaklığındaki $100 \mathrm{~mL}$ su ilave edilerek karıştırılmak suretiyle gaz çıkışı gözlenmiştir. Yaklaşık 24 saat boyunca, çıkan gaz beherdeki su içinde bulunan mezurda toplanmış ve toplanan gaz miktarı ölçülmüştür [8].

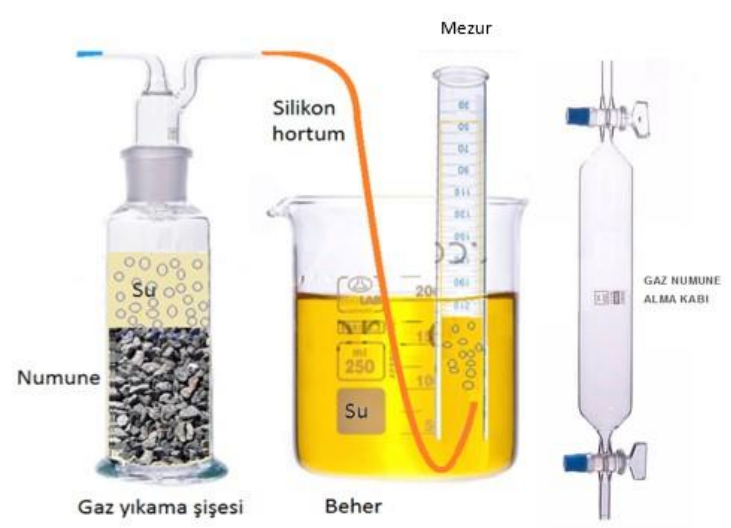

Şekil 9. Test Düzeneği

Söz konusu deney, benzer iki ayrı numunede $25{ }^{\circ} \mathrm{C}$ ve $60{ }^{\circ} \mathrm{C}$ sıcaklığındaki su ile ayrı ayrı yapılmıştır. Diğer test düzeneğinde ise, yıkanmış ve dolayısıyla tuzundan arındırılmış alüminyum cürufu kullanılmış ve deney yine $25{ }^{\circ} \mathrm{C}$ ve $60{ }^{\circ} \mathrm{C}$ sicaklığındaki su ile ayrı ayrı yapılmıştır. Bu deneyde dikkate değer bir gaz çıkışı olmadığı gözlenmiştir. Yıkanmamış 50 gr alüminyum cürufu $25{ }^{\circ} \mathrm{C}$ sıcaklıktaki su ile yapılan test sonucunda, $23 \mathrm{~mL}$ kadar gaz meydana geldiği ve yıkanmış 50 gr alüminyum cürufu yine $25{ }^{\circ} \mathrm{C}$ sıcaklıktaki su ile yapılan test sonucundan ise eser miktarda gaz çıkışı olduğu görülmüştür. Yine yıkanmamış 50 gr alüminyum cürufu $60{ }^{\circ} \mathrm{C}$ sicaklıktaki su ile yapilan test sonucunda $24 \mathrm{~mL}$ kadar gaz meydana geldiği ve ayrıca yıkanmış 50 gr alüminyum cürufu $60{ }^{\circ} \mathrm{C}$ sıcaklıktaki su ile yapılan test sonucunda ise eser miktarda gaz çıkışı olduğu görülmüştür [8]. 
İki farklı sicaklıkta $\left(25{ }^{0} \mathrm{C}\right.$ ve $\left.60{ }^{\circ} \mathrm{C}\right)$ su ile çözülebilen tuz miktarları yaklaşık olarak eşit olduğu görülmektedir. Bu sıcaklıklardaki su ile alüminyum cüruf içerisinde çözülebilen tuz miktarı fark1 yaklaşık \% 2 kadardır [12]. $60{ }^{\circ} \mathrm{C}$ sicaklıkta su ile yıkama yaparak yaklaşık \% 2 kadar fazla tuz cüruftan alınmaktadır. $60{ }^{\circ} \mathrm{C}$ sıcaklıkta su ile yıkama yapmanın çok fazla avantajlı olmadığı görülmektedir Tesiste uygulanacak olan prosesin amacının, cüruf içindeki tuzların ayrıştırılması olduğuna göre, düşük sıcaklıkta (oda sıcaklığında 25 $\left.{ }^{0} \mathrm{C}\right)$ yıkanarak tuzların alınabildiği ve enerji ekonomisi açısından daha uygun olacaktır [8-9].

\subsection{3. Çıkan Gazın Yönetmeliğe Göre Durumu}

Deney sonucunda; $50 \mathrm{gr}$ alüminyum cürufunun, 25 ${ }^{\circ} \mathrm{C}$ ve $60{ }^{\circ} \mathrm{C}$ sıcaklığındaki su ile yıkanmasına bağlı olarak sırasıyla $23 \mathrm{~mL}$ ve $24 \mathrm{~mL}$ toplam gaz çıkışı olduğu görülmüştür. Dolayısıyla, yıkanmamış bir ton tuzlu kara alüminyum cürufunun oda sıcaklığında $\left(25^{\circ} \mathrm{C}\right)$ yıkanması sonucunda yaklaşık $0,46 \mathrm{~m} 3 /$ gün gaz çıkacaktır. Örneğin günlük cüruf yıkama kapasitesinin yaklaşık 100 ton/gün olduğu kabul ettiğimiz bir tesis göz önüne alındığında da, günlük toplam gaz hacminin yaklaşık $62 \mathrm{~m}^{3} /$ gün olacağı, günde yaklaşık 16 saat çalışıldığında da saatlik gaz hacminin yaklaşık $3.8 \mathrm{~m}^{3} / \mathrm{h}$ olacaktır [8].
Analizler içerisinde karbon, fosfür ve sülfürlü bileşiklerin bulunmadığı görülmektedir. Bu analizler incelendiğinde cüruf içerisinde AlN (alüminyum nitrür) fazla miktarda olduğu ve sırası ile $\mathrm{Al}_{2} \mathrm{MgO}_{4}$ (magnesium aluminate), $\mathrm{NaCl}$ (sodyum klorür) ve $\mathrm{Al}_{2} \mathrm{O}_{3}$ (alüminyum oksit) bileşiklerinin olduğu görülmektir. Dolayısıyla alüminyum cürufunun yıkama prosesi sonucunda içerdiği element ve bileşiklerden dolayı sadece amonyak $\left(\mathrm{NH}_{3}\right)$, eser miktarda hidrojen $\left(\mathrm{H}_{2}\right)$ ve eser miktarda metan $\left(\mathrm{CH}_{4}\right)$ gazları çıkışı olacaktır [8].

Yıkama sonucunda çıkan gazın debisi yaklaşık $1.1 \times 10^{-3} \mathrm{~m}^{3} / \mathrm{s}$ olup, yanma için lel hacmi oluşturmamaktadır. Bu yüzden ortamda yanma riski oluşturmaz. Yanma gerçekleşse bile çabuk söner. Y1kama sonucu örnek tesisten çıkacak günlük gaz miktarının $62 \mathrm{~m}^{3} /$ gün, saatlik gaz miktarının $3.8 \mathrm{~m}^{3} / \mathrm{h}$ olduğu esas alındığında ve ortalama gaz yoğunluğu da yaklaşık $0,66 \mathrm{~kg} / \mathrm{m}^{3} \mathrm{kabul}$ edildiğin de, çıkan gazın saatlik kütlesel debisinin de yaklaşı $2,6 \mathrm{~kg} / \mathrm{h}$ olacaktır. Alüminyum cüruf yıkama kapasitesinin yaklaşık 100 ton/gün olduğu kabul ettiğimiz bir örnek tesisten çıkacak toplam gaz miktarı yaklaşık 2,6 kg/h olacaktır. Bu değerin, Sanayi Kaynaklı Hava Kirliliğinin Kontrolü Yönetmeliği' de belirtilen değerlerin altında olduğu görülmektedir [8,10]. Tablo 1'de Sanayi Kaynaklı Hava Kirliliğinin Kontrolü Yönetmeliği'görülmektedir [10].

Tablo 1. Sanayi Kaynaklı Hava Kirliliğinin Kontrolü Yönetmeliği( Ek-2 Tablo 2.1 Kütlesel Debiler) [10]

\begin{tabular}{|l|l|l|}
\hline \multirow{2}{*}{ Emisyonlar } & \multicolumn{2}{l|}{$\begin{array}{l}\text { Normal işletme şartlarında ve haftalık iş günlerindeki işletme } \\
\text { saatleri ç̧in kütlesel debiler (kg/h) }\end{array}$} \\
\cline { 2 - 3 } & Bacadan & Baca Dişındaki Yerlerden \\
\hline \multirow{2}{*}{ Toz } & 10 & 1 \\
\hline Kurşun & 0.5 & 0.05 \\
\hline Kadmiyum & 0.01 & 0.001 \\
\hline Talyum & 0.01 & 0.001 \\
\hline Klor & 20 & 2 \\
\hline $\begin{array}{l}\text { Hidrojen klorür ve Gaz Halde İnorganik } \\
\text { Klorür Bileşikleri }\end{array}$ & 20 & 2 \\
\hline $\begin{array}{l}\text { Hidrojen florür ve Gaz Halde İnorganik } \\
\text { Florür Bileşikleri }\end{array}$ & 2 & 0.2 \\
\hline Hidrojen Sülfür & 4 & 0.4 \\
\hline Karbon Monoksit & 500 & 50 \\
\hline Kükürt Dioksit & 60 & 6 \\
\hline Azot Dioksit [NO ${ }_{x}\left(\mathrm{NO}_{2}\right.$ cinsinden $\left.)\right]$ & 40 & 4 \\
\hline Toplam Organik Bileşikler & 30 & 3 \\
\hline Not: Tablodaki emisyonlar işletmenin tamamindan (bacaların toplamı) yayılan saatlik kütlesel debilerdir. \\
\hline
\end{tabular}




\subsubsection{Ts 13644 Standardının incelenmesi ve Değerlendirilmesi}

TS 13644 standard1, çelik üretiminde flaks ürün olarak kullanılacak alüminyum esaslı flaksların tarifini, sınıflandırmasını, özelliklerini, numune almayı ve yapılacak deneyler ile piyasaya arz esaslarını kapsamaktadır. Bu standard da belirtilen flaks, çelik üretiminde oksijen giderici/önleyici ve cüruf akışkanlaştırıcı/çöktürücü olarak kullanılmak amacıyla, alüminyum cürufunun içerisindeki zararlı içeriklerin (azot, kriyolit, flor, klor ve silisyum dioksit vb.) belirli (bu değerler Çevre ve Şehircilik Bakanlığı yetkilerinden alınan) değerlerin altına düşürülmesi ile elde edilen üründür. Bu flaks ürün, metalik alüminyum içeriğine göre; Sınıf A, Sınıf B , Sinıf C ve Sinıf D olmak üzere 4 sinıfa ayrılmaktadır. Alüminyum oksit içeriğine göre; Sınıf $E$, Sinıf $F$ ve Sinıf $G$ olmak üzere 3 sinıfa ayrılmaktadır. Yine piyasaya, peletlenmemiş yani parçacık olarak ve pelet haline getirilerek piyasaya arz edilmektedir. Peletlenmiş flaksın boyutu, $10 \mathrm{~mm}$ ile $100 \mathrm{~mm}$ aralığındadır. Pelet flaks üretiminde kireç ve/veya herhangi bir organik bağlayıcı dışında bir katkı maddesi kullanılmamaktadır. Parçacık boyutunda, herhangi bir bağlayıcı katılmayan alüminyum cürufu ise $2 \mathrm{~mm}$ ile $100 \mathrm{~mm}$ aralığında boyutlarındadir [11].

Standard da flaksın kimyasal özellikleri: A, B, C, D sınıfı flaksların kimyasal özellikleri Tablo 2'e, E, F ve G sınıfı flaksların kimyasal özellikleri Tablo 3'e uygun olmalidir [11].

Tablo 2. A, B, C, D sınıfı flaksların kimyasal özellikleri [11]

\begin{tabular}{|c|c|c|c|c|c|c|c|c|c|}
\hline Sinif & $\begin{array}{c}\text { Metalik } \\
\text { Alüminyum } \\
\text { içeriği } \\
\%\end{array}$ & $\begin{array}{c}\text { Alüminyum } \\
\text { oksit içeriği } \\
\% \\
\text { En az }\end{array}$ & $\begin{array}{c}\text { Azot } \\
\text { içeriği } \\
\% \\
\text { En fazla }\end{array}$ & $\begin{array}{l}\text { Kriyolit } \\
\text { içeriği \% } \\
\text { En fazla }^{a}\end{array}$ & $\begin{array}{c}\text { Toplam } \\
\text { Flor } \\
\text { içeriği } \\
\text { \% En } \\
\text { fazla } \\
\end{array}$ & $\begin{array}{c}\text { Toplam } \\
\text { Klor } \\
\text { içeriği } \\
\% \\
\text { En fazla } \\
\end{array}$ & $\begin{array}{c}\text { Silisyum } \\
\text { dioksit } \\
\text { içeriği } \\
\% \\
\text { En fazla } \\
\end{array}$ & $\begin{array}{c}\text { Karbon } \\
\text { içeriği } \\
\% \\
\text { En fazla }\end{array}$ & $\begin{array}{c}\text { Nem içeriği } \\
\% \\
\text { En fazla }\end{array}$ \\
\hline $\mathbf{A}$ & $40-50$ & 25 & 5 & 3 & 1.63 & 1 & 10 & 5 & 2 \\
\hline B & $30-40$ & 25 & 5 & 3 & 1.63 & 1 & 10 & 5 & 2 \\
\hline C & $20-30$ & 30 & 5 & 3 & 1.63 & 1 & 10 & 5 & 2 \\
\hline D & $5-20$ & 40 & 5 & 3 & 1.63 & 1 & 10 & 5 & 2 \\
\hline
\end{tabular}

a) Kriyolit yüzdesi, flor kütle yüzdesi tayini yapılarak hesaplanır.

Not- İçerikler kütle oranı cinsinden hesaplanır.

Tablo 2'de metalik alüminyum içeriği önemli olup sınıflandırma bu orana göre yapılmaktadır. Sınıf A, metalik alüminyum içeriği en fazla olan ve alüminyum oksit içeriği en az olan flaks türüdür. Sınıf D ise metalik alüminyum içeriği az olan ve alüminyum oksit içeriği en fazla olan flaks türüdür.

Tablo 3. E,F, G sınıfı flaksların kimyasal özellikleri [11]

\begin{tabular}{|c|c|c|c|c|c|c|c|c|c|}
\hline Sinıf & $\begin{array}{c}\text { Metalik } \\
\text { Alüminyum } \\
\text { içeriği } \\
\% \\
\text { En Fazla }\end{array}$ & $\begin{array}{c}\text { Alüminyum } \\
\text { oksit içeriği } \\
\% \\
\text { En az }\end{array}$ & $\begin{array}{c}\text { Azot } \\
\text { içeriği } \\
\% \\
\text { En fazla }\end{array}$ & $\begin{array}{c}\text { Kriyolit } \\
\text { içeriği } \\
\% \\
\text { En fazla }^{a}\end{array}$ & $\begin{array}{c}\text { Toplam } \\
\text { Flor } \\
\text { içeriği } \\
\% \\
\text { En fazla }\end{array}$ & $\begin{array}{c}\text { Toplam } \\
\text { Klor } \\
\text { içeriği } \\
\% \\
\text { En fazla }\end{array}$ & $\begin{array}{c}\text { Silisyum } \\
\text { dioksit } \\
\text { içeriği } \\
\% \\
\text { En fazla }\end{array}$ & $\begin{array}{c}\text { Karbon } \\
\text { içeriği } \\
\% \\
\text { En fazla }\end{array}$ & $\begin{array}{c}\text { Nem içeriği } \\
\% \\
\text { En fazla }\end{array}$ \\
\hline $\mathbf{E}$ & 20 & 65 & 5 & 3 & 1.63 & 1 & 10 & 5 & 2 \\
\hline $\mathbf{F}$ & 15 & 60 & 5 & 3 & 1.63 & 1 & 10 & 5 & 2 \\
\hline $\mathbf{G}$ & 15 & 50 & 5 & 3 & 1.63 & 1 & 10 & 5 & 2 \\
\hline
\end{tabular}

Tablo 3'de ise alüminyum oksit içeriği önemli olup sınıflandırma bu orana göre yapılmaktadır. Sınıf E, alüminyum oksit içeriği ve metalik alüminyum içeriği en fazla olan flaks türüdür. Sınıf $G$ ise alüminyum oksit içeriği ve metalik alüminyum içeriği en az olan flaks türüdür.

Peletlenmiş veya peletlenmemiş flaks (parçacık) ürün için azot içeriği en fazla $\% 5$, kriyolit içeriği \% 3 , toplam flor içeriği \% 1,63, toplam klor içeriği \% 1 olmalıdır. Azot, flor dolayısıyla kriyolit, klor sınır değerleri, Çevre ve Şehircilik Bakanlığg yetkilileri tarafindan Avrupa uyum yasaları gereği olması istenmiştir. Ayrıca çelik üretiminde pota aşınmasının önlemesi amacı ile flaks içindeki silisyum dioksit içeriği \% 10 ve karbon oranının \% 5' i aşmaması isteği çelik üreticileri tarafından istenmiştir. Flaks içindeki neminde en fazla \% 2 olması şeklinde yapılan toplantılar sonunda görüş oluşmuş ve standard bu haliyle oluşturulmuştur.

Alüminyum cürufu( beyaz, kara ve özellikle tuz keki), standarda belirtilen kimyasal ve fiziksel özellikleri sağlanarak flaks ürün elde edilecektir. Alüminyum cürufundan Sınıf A'dan G kadar çeşitli 
tiplerde flaks üretimi yapılması mümkündür. İhtiyaç makamı olan çelik üreticilerin istediği boyut ve türdeki flaks ürünü temin edebilmesi ve yurt dışından temin edilen toz halindeki kalsiyum alüminat veya kalsiyum flörür ve $100-500$ gr kütleli alüminyum parçaların yerine bu flaks ürünler kullanılması uygun görülmektedir. Flaks ürünler sayesinde yurt dişından temin edilen kalsiyum alüminat veya kalsiyum flörür gibi kimyasal tozların alınması önlenmiş olacak ve 100 -500 gr kütleye sahip alüminyum parçalar kullanılmayacaktır. Direk olarak bu flak ürün kullanılmak suretiyle ekonomik kazanç söz konusu olacaktır.

\section{SONUÇ}

Birincil ve ikincil üretimden tehlikeli atık olarak çıkan beyaz ve kara cüruf, tuz keki içerisinde önemli miktarlarda alüminyum metali bulunmaktadır. Ayrıca atıkların içerisinde bulunan $\mathrm{NaCl}$ ve $\mathrm{KCl}$ tuzları çevre için ciddi sorunlar oluşturmaktadırlar. $\mathrm{Bu}$ atıkların yaklaşık \% 95'i de gömülmek suretiyle bertaraf edilmekte veya atı ara depolama tesislerine/İzaydaş' a bertaraf ücreti ödemek suretiyle bertaraf edilmesi sağlanmaktadır. Özellikle alüminyum külçe üreticileri bu atığı ücret ödeyerek bertarafa verme zorunluluğu vardır. Ayrıca alüminyum metali üretimi sonucunda ortaya çıkan alüminyum oksit ve metalik alüminyum ihtiva eden beyaz ve kara cüruf atıkların içerisinde \%15-70 arasında geri dönüşebilir metalik alüminyum ve tuz keki içerisinde minumum $\% 5$ oranında alüminyum metali bulunmaktadır. Bugün en iyi teknolojilerle cüruftan \% 94'e kadar geri dönüşüm ile metalik

\section{KAYNAKÇA}

[1] E. Petavratzi and W. Scott, "Residues from aluminium dross recycling in cement", Characterisation of Mineral Wastes, Resources and Processing Technologies, November 2007, pp.1-8.

[2] J.Y. Hwang, X. Huang X and Z. Xu, "Recovery of Metals from Aluminium Dross and Salt Cake", Journal of Minerals \&Metarials characterization \& Engineering, 2006; vol.5,pp. 47-62.

[3] P.E. Tsakiridis, "Aluminium salt slag characterization and utilization - A review" Journal of Hazardous Materials 217- 218 (2012) 1- 10.

[4] M.Öztürk, "Kullanılmış Alüminyum Malzemelerinin Geri Kazanılması, Çevre ve Orman Bakanlığı, Rapor, Ankara, (2005).

[5] N. Sözbir, M. Akçil, ve H. Okuyucu, "Alüminyum Cürufundan Alüminyum Metali ve Flaks Eldesi”, ISEM2014 Adıyaman, 1108-113, (2014.

[6] O. Yücel ve E. Car,"Alüminyum cüruflarının değerlendirilmesi ve klasiyum alüminat sentetik alüminyum elde etmek mümkündür. İçerisinde minumum $\% 5$ alüminyum metali bulunan cürufun veya daha fazla alüminyum metali içeren cürufun gömülmesi veya bertarafa verilmesi ülke ekonomisi açısından uygun değildir. Bu ciddi bir ekonomik kayıptır.

Bugün çelik üreticilerin çelik üretiminde sıvı çeliğin oksitlenmesini önlemek amacı ile kalsiyum alümünat ve kalsiyum florür kullanmaktadırlar. $\mathrm{Bu}$ ürünlerin tonu, yaklaşı 300 Amerikan doları civarındadır. Bununla birlikte çeliğin veya cürufun kayganlaştırıcılığını sağlamak amacı ile 100 -500 gr kütleli alüminyum metal parçalar kullanılmaktadır. $\mathrm{Bu}$ ürünün fiyatı ise yaklaşık $7500 \mathrm{TL} /$ ton 'dur. Kalsiyum alüminat veya kalsiyum flörür ve alüminyum parçalar kullanmak yerine atık olan alünyum cürufunun tuzlardan arındırılarak TS 13644 belirtilen şartların sağlanması koşulu ile flaks ürünlere dönüştürülmesi ve bu ürünlerin çelik sanayisinde kullanılması, çelik üreticileri için ucuz ve ekonomik bir hammadde olacaktır. Ayrıca bu atıkların çevreye olumsuz etkileride önlenmiş olacaktır. İçerisinde belli oranlar da alüminyum metali ve alüminyum oksit bulunan cürufların yıkanmak suretiyle rehabillite edilerek flaks elde edilmesi ülkemize ekonomik açıdan ciddi bir katkı sağlayacaktır. Alüminyum cüruftan elde edilen bu ürünü kullanmak suretiyle yurt dışından temin edilen kalsiyum alüminat ve kalsiyum florür gibi kimyasal tozlar için döviz harcanmayacak ve ülkemizde tehlikeli atık olan alüminyum cürufu oluştuurlan standard sayesinde ürüne dönüştürülerek ülke ekonomisine katkı sağlayacaktır.

cüruf yapıc1 üretimi”, Türk Mühendis ve Mimar Odaları Birliği Metalurji ve Malzeme Mühendisleri Odası, Metalurji Sayı:175, Ağustos 2015.

[7) N.Sözbir, A. Ateş ve M. Akçil, Alüminyum Cürufundan Çelik Endüstrisi için Flaks Üretimi, ISEM 2016, 3. International Symposium on Environment and Morality, 04-06 November 2016, Alanya, Türkiye.

[8] N. Sözbir, A. Manzak, M. Teker ve Ü. Uysal, "Alüminyum Cürufundan Flaks Üretilirken Oluşan Gazın İncelenmesi”, 3rd. ISEM2016, 3. International Symposium on Environment and Morality, 04-06 November 2016, Alanya, Türkiye.

[9] A. B. Yoruç ve M. Çiğdem, "Tuzlu Alüminyum Cüruflarının Değerlendirilmesi”Yı1dız Teknik Üniversitesi, Kimya-Metalurji Fakültesi, Metalurji ve Malzeme Mühendisliği Bölümü (2001).

[10] Sanayi Kaynaklı Hava Kirliliğinin Kontrolü Yönetmeliği, Resmi Gazete, Sayı:29211, 20 Aralık 2014.

[11] TSE 13644,“Alüminyum Esaslı Flakslar- Çelik Endüstrisi için”, Aralık 2014 (Rapörtör Doç:Dr. Nedim Sözbir). 